\title{
UPAYA PENINGKATAN PRESTASI KINERJA GURU MELALUI TEKNIK MEETING KEPALA SEKOLAH
}

\author{
I Ketut Ngurah Suka Darmasada
}

\author{
SMA Negeri 1 Mendoyo \\ e-mail: sukadarmaikn@gmail.com
}

\begin{abstract}
Abstrak
Penelitian ini bertujuan: 1). Untuk mendeskripsikan tentang Teknik Meeting oleh kepala sekolah sebagai upaya peningkatan prestasi kinerja guru SMA Negeri 1 Mendoyo, dan 2).Untuk mengetahui seberapa besar pengaruh Teknik Meeting oleh kepala sekolah terhadap prestasi kinerja guru SMA Negeri 1 Mendoyo. Subjek penelitian adalah seluruh guru SMA Negeri 1 Mendoyo yang berjumlah 42 orang pada tahun pelajaran 2019/2020. Adapun data yang diamati selama penelitian ini adalah kinerja guru dan Teknik Meeting, data tersebut dikumpulkan dengan menggunakan kuesioner/lembar observasi yang telah ditetapkan sesuai dengan pedoman. Setelah data terkumpul akan dianalisis dengan menggunakan analisis deskriptif yaitu mencari prosentase ketercapaian sesuai dengan indikator keberhasilan yang telah ditetapkan dalam penelitian tindakan sekolah ini. Seluruh kegiatan pada penelitian ini dilaksanakan hanya 2 siklus, dimana setiap siklus terdiri dari 4 tahap, yaitu: 1). Perencanaan Tindakan, 2). Pelaksanakan Tindakan, 3). Pengamatan/observasi Tindakan, dan 4), Refleksi. Hasil penelitian dapat dikemukakan yaitu sebagai berikut: 1). Ada peningkatan prestasi kinerja guru yang sangat signifikan melalui Teknik meeting kepala sekolah di SMA Negeri 1 Mendoyo. Ini terbukti dari hasil nilai analisis siklus I rerata persentasenya adalah $64,40 \%$ meningkat menjadi $76,47 \%$ pada siklus II, dan 2). Besarnya pengaruh supervisi kepala sekolah terhadap kinerja guru-guru SMA Negeri 1 Mendoyo dalam penelitian ini adalah 12,07\%. Jadi berdasarkan hasil analisis yang telah ditekuman dalam penelitian tindakan sekolah ini, maka penulis dapat mengambil simpulan bahwa: Upaya peningkatan prestasi kinerja guru SMA Negeri 1 Mendoyo, ternyata dapat ditingkatkan melalui Teknik Meeting Kepala Sekolah dengan hasil yang sangat signifikan.
\end{abstract}

Kata kunci: Prestasi Kinerja Guru, dan Teknik Meeting.

\begin{abstract}
This research aimsed: 1). To describe the Meeting Technique by the principal as an effort to improve teacher's performance achievement at SMA Negeri 1 Mendoyo, and 2). To find out how much the influence of Meeting Technique on the teacher performance achievement of SMA Negeri 1 Mendoyo. Research subjects were all 42 teachers at SMA Negeri 1 Mendoyo in 2019/2020. The data observed during this study were teacher performance and Meeting Techniques, the data was collected using questionnaire / observation sheet that had been determined in accordance with the guidelines. After the data collected, it will be analyzed using descriptive analysis that is looking for the percentage of achievement in accordance with the indicators of success that have been determined in this action research. All activities in this study were carried out in 2 cycles, where each cycle consisted of 4 stages: 1). Planning, 2). Implementing, 3). Observation, and 4), Reflection. The results of the study can be stated as follows: 1). There is a very significant increase in teacher performance through the Principal's meeting technique at SMA Negeri 1 Mendoyo. This is evident from the results score of the first cycle analysis, the percentage was $64.40 \%$, increase to $76.47 \%$ in the second cycle, and 2). The magnitude of the effect of the supervision of school principals on the teacher's performance at SMA Negeri 1 Mendoyo in this study was $12.07 \%$. So, based on the results of the analysis that has been recorded in this school action research, the researcher can conclude that: Efforts to improve the teachers performance achievements at SMA Negeri 1 Mendoyo can be improved through the Principal Meeting Technique with very significant results.
\end{abstract}

Keywords: Teacher Performance Achievements, and Meeting Techniques. 


\section{Pendahuluan}

Pendidikan merupakan salah satu bidang yang mempunyai peranan besar dalam pembangunan di suatu negera selain bidang ekonomi, politik, keamanan, dan sebagainya. Maju mundurnya bangsa banyak ditentukan oleh maju mundurnya pendidikan, oleh karena itu pendidikan harus dilaksanakan sebaikbaiknya agar memperoleh hasil yang maksimal. Pendidikan di Indonesia masih tertinggal dari negara-negara lain, salah satu faktornya belum sadarnya masyarakat tentang pentingnya pendidikan dan dengan banyaknya siswa yang tidak melanjutkan ke jenjang pendidikan yang lebih tinggi, maka dari itu Pendidikan di Indonesia yang berakar pada kebudayaan bangsa berdasarkan Pancasila dan UndangUndang Dasar 1945 terus ditata, dikembangkan, dilengkapi berbagai ketentuan peraturan serta mengutamakan pemerataan dan peningkatan kualitas pendidikan. Upaya ini perlu didukung oleh sumber daya pendidikan secara bertahap disertai keterpaduan dan efisiensi pelaksanaannya sehingga mampu memenuhi tuntutan dan kebutuhan pembangunan di Indonesia (Firmansyah, 2015).

Pendidikan merupakan sesuatu yang memiliki tujuan yang sangat penting untuk diperoleh. Dalam skala nasional, tujuan dalam pendidikan adalah untuk mengembangkan kemampuan dan membentuk watak serta peradaban bangsa yang bermartabat dalam rangka mencerdaskan kehidupan bangsa, serta untuk mengembangkan potensi peserta didik agar menjadi manusia yang beriman dan bertakwa kepada Tuhan Yang Maha Esa, berakhlak mulia, sehat, berilmu, cakap, kreatif, mandiri, dan menjadi warga negara yang demokratis serta bertanggung jawab. Artinya bahwa tujuan pendidikan adalah membentuk orang yang mempunyai sikap atau attitude sosial yang baik, yang mampu bekerja sama dengan lingkungannya, mampu mengutamakan kepentingan umum dari pada kepentingan sendiri atau golongan (Thahir, 2014).

Mengajar dalam konteks proses pembelajaran tidak hanya sekedar mempunyai materi pembelajaran, akan tetapi juga dimaknai sebagai proses mengatur lengkungan supaya peserta didik belajar. Walaupun istilah yang digunakan "pembelajaran". Tidak berarti guru harus menghilangkan perannya sebagai pengajar. Dalam konteks pembelajaran, sama sekali tidak berarti memperbesar peranan peserta didik disatu pihak dan memperkecil peranan guru dipihak lain. Peran guru dan peserta didik yang dimaksud di sini adalah berkaitan dengan peran dalam proses pembelajaran. Guru dan peserta didik merupakan faktor penentu yang sangat dominan dalam pendidikan umumnya, karena guru dan peserta didik memegang peranan dalam proses pembelajaran, di mana proses pembelajaran merupakan inti dari proses pendidikan secara keseluruhan yang bertujuan terjadinya perubahan tingkah laku anak (Kirom, 2017).

Slamat dalam Sagala (2013) mengemukakan wacana mengenai istilah kompetensi. Menurut beliau kompetensi profesional diganti dengan kompetensi bidang studi (subject matter competency). Istilah kompetensi kepribadian diganti dengan istilah kompetensi etika profesi. Guru juga harus diberikan kepercayaan. Di samping untuk melaksanakan tugasnya sebagai guru, yakni melakukan proses belajar mengajar yang baik. Kepada mereka juga perlu diberikan dorongan dan suasana yang kondusif untuk menemukan berbagai alternatif metode dan cara mengembangkan proses pembelajaran yang sesuai dengan kemampuan guru dan perkembangan jaman (Fitriani, 2017).

Dalam pelaksanaan fungsi dan tugasnya, guru sebagai profesi menyandang persyaratan tertentu sebagaimana tertuang di dalam Undang-Undang Republik Indonesia Nomor 20 tahun 2003 tentang Sistem Pendidikan Nasional. Dalam pasal 39 (1) dan (2) dinyatakan bahwa: Tenaga kependidikan bertugas melaksanakan administrasi, pengelolaan, pengembangan, pengawasan, dan pelayanan teknis untuk menunjang proses pendidikan pada satuan pendidikan.

Untuk dapat melaksanakan tugas dan tanggung jawab diatas, seorang guru dituntut memiliki beberapa kemampuan dan ketrampilan tertentu. Kemampuan dan ketrampilan tersebut sebagai bagian dari kompetensi profesionalisme guru. Kompetensi merupakan suatu kemampuan yang mutlak dimiliki oleh guru agar tugasnya sebagai pendidik dapat terlaksana dengan baik. 
Tugas guru erat kaitannya dengan peningkatan sumber daya manusia melalui sektor pendidikan, oleh karena itu perlu upaya-upaya untuk meningkatkan mutu guru untuk menjadi tenaga profesional. Agar peningkatan mutu pendidikan dapat berhasil. Sebagaimana dikemukakan oleh Tilaar (1999:104) peningkatan kualitas pendidikan tergantung banyak hal, terutama mutu gurunya.Menurut UU No.20 tahun 2003 tentang Sistem Pendidikan Nasional bahwa pendidikan adalah usaha sadar dan terencana untuk mewujudkan suasana belajar dan proses pembelajaran agar peserta didik secara aktif mengembangkan potensi dirinya untuk memiliki kekuatan spiritual keagamaan, pengendalian diri, kepribadian, kecerdasan, akhlak mulia, serta ketrampilan yang diperlukan dirinya, masyarakat, Bangsa dan Negara.

Untuk menjadikan guru sebagai tenaga profesional maka perlu diadakan pembinaan secara terus menerus dan berkesinambungan, dan menjadikan guru sebagai tenaga kerja perlu diperhatikan, dihargai dan diakui keprofesionalannya. Membuat mereka menjadi profesional tidak semata-mata hanya meningkatkan kompetensinya baik melalui pemberian penataran, pelatihan maupun memperoleh kesempatan untuk belajar lagi namun perlu juga memperhatikan guru dari segi yang lain seperti peningkatan disiplin, pemberian motivasi, pemberian bimbingan melalui supervisi, pemberian insentif, gaji yang layak dengan keprofesionalnya sehingga memungkinkan guru menjadi puas dalam bekerja sebagai pendidik.

Kepuasan kerja bagi guru sebagai pendidik diperlukan untuk meningkatkan kinerjanya. Kepuasan kerja berkenaan dengan kesesuaian antara harapan seseorang dengan imbalan yang disediakan. Kepuasan kerja guru berdampak pada prestasi kerja, disiplin, kualitas kerjanya. Pada guru yang puas terhadap pekerjaannya maka kinerjanya akan meningkat kemungkinan akan berdampak positif terhadap peningkatan mutu pendidikan.

Kinerja guru atau prestasi kerja adalah suatu hasil kerja yang dicapai seseorang dalam melaksanakan tugas-tugas yang dibebankan kepadanya yang didasarkan atas kecakapan, pengalaman, dan kesungguhan serta waktu (Hasibuan, 2001:94). Kinerja guru akan baik jika guru telah melakukan unsur-unsur yang terdiri dari kesetiaan dan komitmen yang tinggi pada tugas mengajar, menguasai dan mengembangkan bahan pelajaran, kedisiplinan dalam mengajar dan tugas lainnya, kreativitas dalam pelaksanaan pengajaran, kerjasama dengan semua warga sekolah, kepemimpinan yang menjadi panutan siswa, kepribadian yang baik, jujur dan objektif dalam membimbing siswa, serta tanggung jawab terhadap tugasnya. Oleh karena itu tugas kepala sekolah selaku manager adalah melakukan penilaian terhadap kinerja guru.

Ada beberapa hal yang menyebabkan meningkatnya kinerja guru, namun penulis mencoba mengkaji masalah supervisi yang diberikan oleh kepala sekolah. Supervisi dalam hal ini adalah mengenai tanggapan guru terhadap pelaksanaan pembinaan dan bimbingan yang diberikan oleh kepala sekolah yang nantinya berdampak kepada kinerja guru yaitu kualitas pengajaran. Supervisi pendidikan didefinisikan sebagai proses pemberian layanan bantuan profesional kepada guru untuk meningkatkan kemampuannya dalam melaksanakan tugas-tugas pengelolaan proses pembelajaran secara efektif dan efisien (Bafadal, 2004:46). Dengan adanya pelaksanaan supervisi oleh kepala sekolah diharapkan memberi dampak terhadap terbentuknya sikap profesional guru.

Sikap profesional guru merupakan hal yang amat penting dalam memelihara dan meningkatkan profesionalitas guru, karena selalu berpengaruh pada perilaku dan aktivitas keseharian guru. Perilaku profesional akan lebih diwujudkan dalam diri guru apabila institusi tempat ia bekerja memberi perhatian lebih banyak pada pembinaan, pembentukan, dan pengembangan sikap profesional (Pidarta, 1996:380).

Kegiatan supervisi kepala sekolah akan berpengaruh secara psikologis terhadap kinerja guru, guru yang puas dengan pemberian supervisi kepala sekolah dan motivasi kerjanya tinggi maka ia akan bekerja dengan sukarela yang akhirnya dapat membuat produktivitas kerja guru meningkat. Tetapi jika guru kurang puas terhadap pelaksanaan supervisi kepala sekolah dan motivasi kerjanya rendah maka guru dalam bekerja kurang bergairah, hal ini mengakibatkan produktivitas guru menurun.

Berdasarkan kenyataan yang ada di SMA Negeri 1 Mendoyo belum maksimal dilakukan supervisi dan masih banyak kendala atau persoalan yang berkaitan dengan 
pelaksanaan supervisi oleh kepala sekolah. Partisipasi guru untuk di supervisi masih rendah, mereka beranggapan bahwa supervisi adalah pengawasan atau penilaian yang akhirnya kondite baginya, maka beberapa guru masih enggan untuk disupervisi. Padahal tujuan supervisi untuk membantu guru-guru melihat dengan jelas tujuan pendidikan dan berusaha mencapai tujuan pendidikan itu dengan membina dan mengembangkan metode-metode dan prosedur pengajaran yang lebih baik.

Bertitik tolak dari uraian di atas maka penulis tertarik untuk mengadakan penelitian sekolah dengan judul "Upaya Peningkatan Prestasi Kinerja Guru Melalui Teknik Meeting Kepala Sekolah di SMA Negeri 1 Mendoyo Tahun Pelajaran 2019/2020"

\section{Metode}

Pada dasarnya desain hanya berfungsi sebagai fasilitas bagi tujuan penelitian dan bersifat prosedural. Oleh karena itu, desain ditentukan oleh masalah penelitian, bukan sebaliknya. Karena tujuan penelitian bervariasi, desain yang sesuai untuk mencapai tujuan tersebut juga bervariasi. Masing-masing desain memiliki karakteristik yang berbeda-beda dan memiliki kelebihan dan kelemahan. Desain penelitian mengacu pada rencana dan struktur menyelidikan yang digunakan untuk memperoleh bukti-bukti emperis dalam menjawab pertanyaan penelitian (McMillan dan Schummacher, 1989).

Karya tulis ilmiah ini mengambil bentuk penelitian tindakan Sekolah (PTS) yaitu usaha Meningkatan disiplin kerja guru dalan proses belajar mengajar melalui supervisi individual dengan pendekatan teknik kunjungan kelas, yang terdiri dari dua siklus dan masing-masing siklus terdiri dari empat tahapan yaitu, (1). perencanaan, (2). pelaksanaan tindakan, (3).observasi/evaluasi, dan (4).refleksi.

Penelitian Tindakan Sekolah (PTS) ini dilaksanakan di SMA Negeri 1 Mendoyo, Kecamatan Mendoyo, Kabupaten Jembrana, Provinsi Bali. Adapun kondisi Guru-guru SMA Negeri 1 Mendoyo sampai saat ini berjumlah 42 orang, dimana 30 PNS, dan 12 guru kontrak provinsi. Untuk memberikan pelayanan terhadap sejumlah peserta didik, dimana sekolah memiliki tenaga pengajar dengan latar belakang sebagai berikut: 1). PNS, dengan ljazah D3 dan S1 dari berbagai jurusan pendidikan, 2). Guru GTT dengan latar belakang pendidikan terakhir berpendidikan jenjang D3 dan jenjang S1 dari berbagai jurusan pendidikan, dan 3). PNS dan Non PNS hanya sebagian yang mengajar pada mata pelajaran yang sesuai dengan latar belakang pendidikannya.

Menurut Arikunto (1998:115), populasi adalah keseluruhan objek penelitian. Maka populasi dalam penelitian ini adalah seluruh guru SMA Negeri 1 Mendoyo yang berjumlah 42 orang. Karena jumlah kurang dari 100, maka semua populasi menjadi subyek penelitian. Hal ini sesuai dengan yang dikemukakan Arikunto (1998:112), apabila subyek kurang dari seratus lebih baik diambil semua sehingga penelitiannya merupakan penelitian populasi.

Data yang telah terkumpul perlu dilakukan analisis untuk dapat disimpulkan. Adapun ananlisis data yang digunakan dalam penelitian ini adalah statistik sederhana yaitu secara kualitatif(deskriptif). Adapun rumus yang dipergunakan untuk menentukan nilai capaian masing-masing subjek penelitian sebagai berikut:

$$
N K=\quad \begin{array}{r}
\Sigma P \\
\Sigma N
\end{array}
$$

\section{Dimana :}

$\Sigma \mathrm{P}=$ Jumlah Skor Capaian

$\Sigma N=$ Jumlah Skor masimal

NK = Nilai Kualifikasi

Nilai Kualifikasi yang telah dianalisis, maka akan disesuaikan dengan pedoman penilaian untuk memberikan ketercapaian kategorinya, seperti pada Tabel berikut ini. 
Indonesian Journal of Educational Research and Review, Vol 3 No 1, Tahun 2020

p-ISSN: 2621-4792, e-ISSN: 2621-8984

Tabel 1. Pedoman Penilaian Kualifikasi

\begin{tabular}{ccc}
\hline No. & Interval Prosentase & Kategori \\
\hline 1 & $76-100 \%$ & Amat Baik (AB) \\
2 & $56-75 \%$ & Baik (B) \\
3 & $26-55 \%$ & Cukup (C) \\
4 & $0-25 \%$ & Kurang (K) \\
\hline & & Sumber: Suharsimi Arikunto (1989:216)
\end{tabular}

\section{Hasil dan Pembahasan}

Data yang telah dikumpulkan baik pada siklus I dan pada Siklus II hanyalah merupakan data atau informasi mentah yang masih perlu di analisis. Adapun langkahlangkah yang ditempuh dalam analisis data dalam penelitian tindakan Sekolah mengambil cara supervisi individual dengan teknik pendekatan kunjungan kelas untuk meningkatkan kinerja guru dalam proses belajar mengajar sehubungan dengan langkah pembelajaran yang baik dan benar.

Jika ditinjau dari nilai rerata kumulatif kualifikasi pada siklus I termasuk dalam kategori baik(B) dengan nilai 77,29 dan nilai persentase $64,40 \%$. Data lebih rinci dapat dilihat pada Tabel di bawah ini.

Tabel 2.Nilai Rerata Skor, Jumlah Skor, dan Rerata Nilai Kualifikasi

\begin{tabular}{ccrc}
\hline Kegiatan & Jumlah Skor & Rereta Skor & $\begin{array}{l}\text { Rerata Nilai } \\
\text { Kualifikasi }\end{array}$ \\
\hline Siklus I & 3246 & 77.29 & 64.40 \\
\hline
\end{tabular}

Sedangkan bentuk grafik histogram dari capaian rerata skor dan rerata nilai kualifikasi dapat ditunjukkan seperti pada gambar berikut ini.

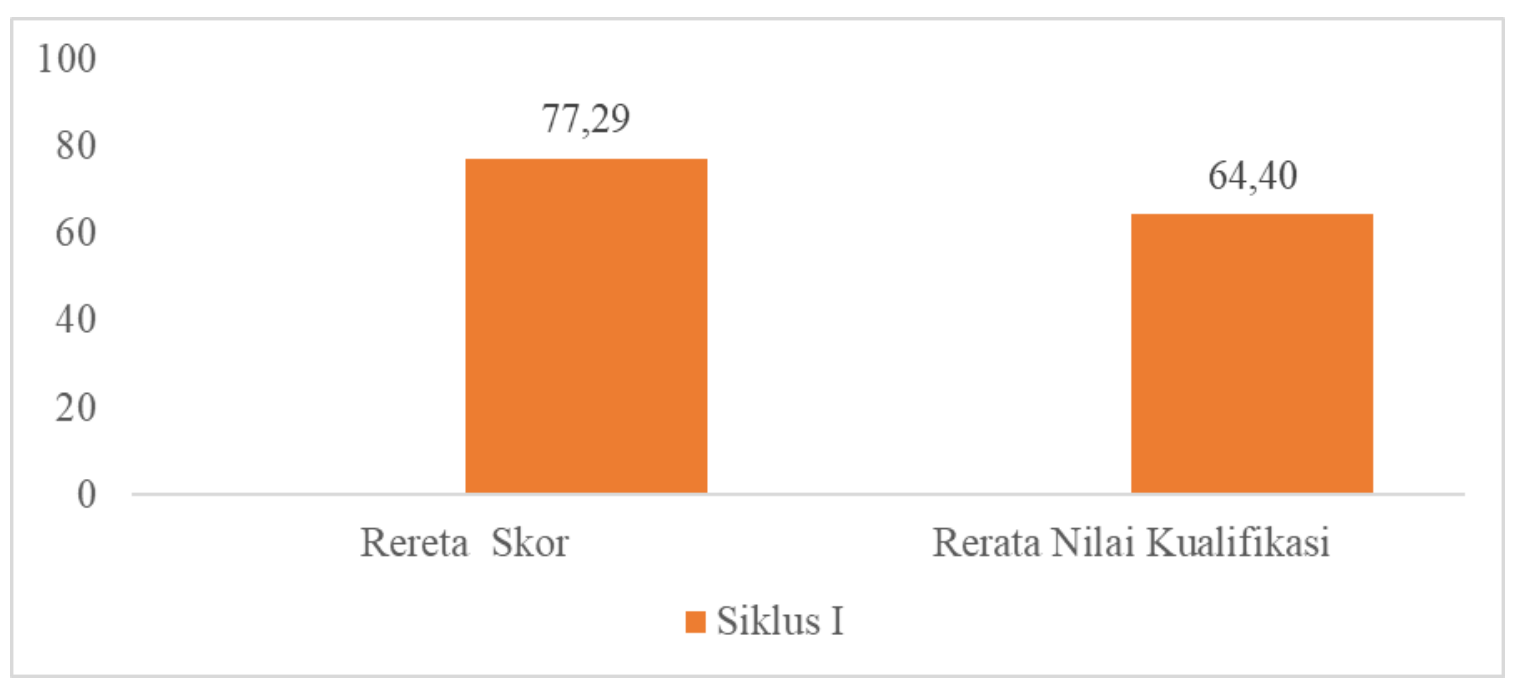

Gambar 1. Grafik Histogram Rerata Skor dan Rerata Nilai Kualifikasi Prestasi Kenerja Guru

Sedangkan dari nilai rerata kumulatif kualifikasi pada Siklus II termasuk dalam kategori baik(B) dengan nilai 91,76 dan nilai persentase $76,47 \%$. Data lebih rinci dapat dilihat pada Tabel di bawah ini. 
Indonesian Journal of Educational Research and Review, Vol 3 No 1, Tahun 2020

p-ISSN: 2621-4792, e-ISSN: 2621-8984

Tabel 3. Nilai Rerata Skor, Jumlah Skor, dan Rerata Nilai Kualifikasi

\begin{tabular}{cccc}
\hline Kegiatan & Jumlah Skor & Rereta Skor & $\begin{array}{c}\text { Rerata Nilai } \\
\text { Kualifikasi }\end{array}$ \\
\hline Siklus II & 3854 & 91.76 & 76.47 \\
\hline
\end{tabular}

Sedangkan bentuk grafik histogram dari capaian rerata skor dan rerata nilai kualifikasi dapat ditunjukkan seperti pada gambar berikut ini.

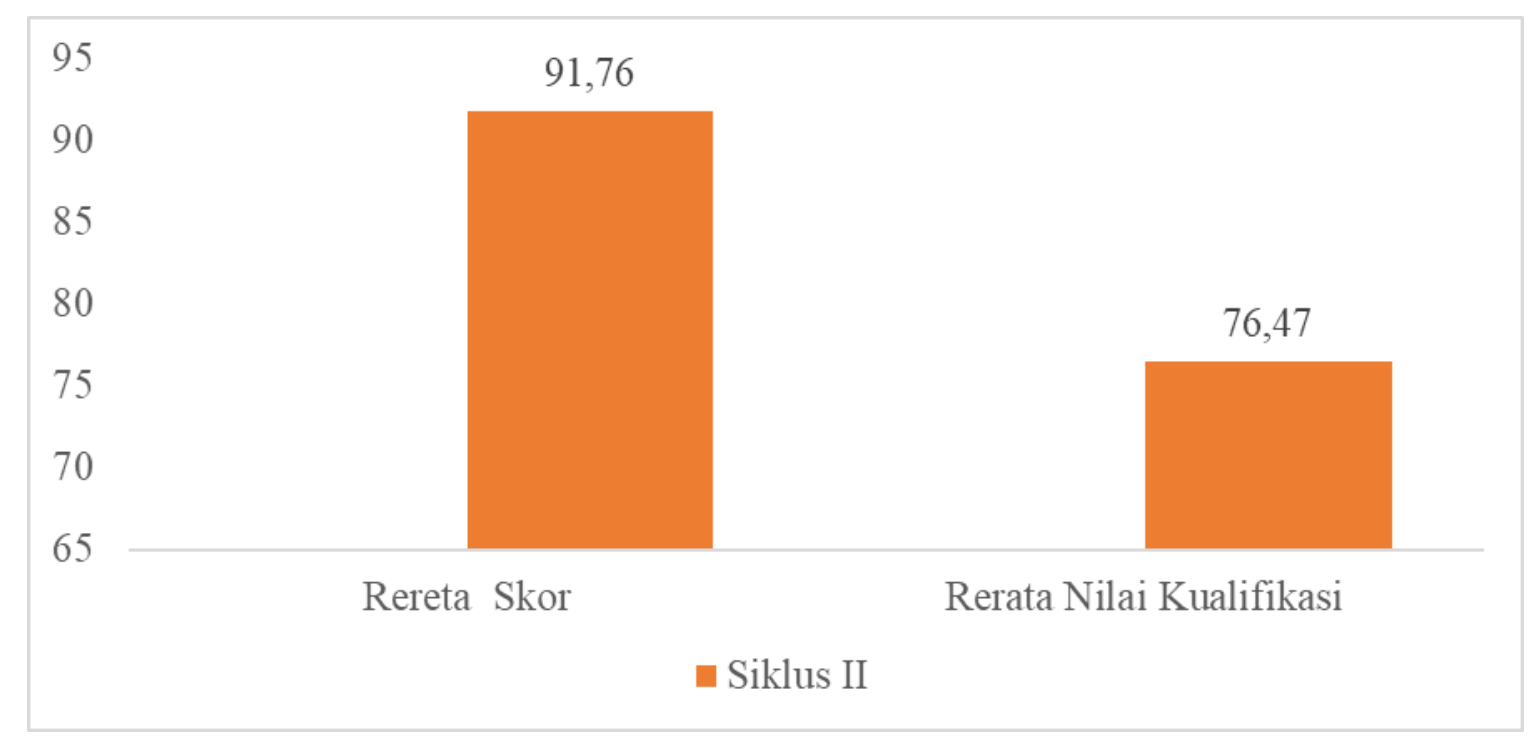

Gambar 2. Grafik Histogram Rerata Skor dan Rerata Nilai Kualifikasi Prestasi Kenerja Guru.

Dari hasil analisis data hasil pengamatan dan dari administrasi perangkat pembelajaran guru-guru yang telah di konversi sesuai dengan kualifikasi yang telah ditetapkan dan setelah di analisis maka dapat rekapitulasi seperti pada tabel berikut ini.

Tabel 4. Rekapitulasi Peningkatan Prestasi Kinerja Guru

\begin{tabular}{lccc}
\hline \multicolumn{1}{c}{ Aspek } & Siklus I & Siklus II & Peningkatan \\
\hline Rerata Skor & 77.29 & 91.76 & 14.47 \\
Rerata Nilai Kualifikasi & 64.40 & 76.47 & 12.07 \\
Kategori & Baik(B) & Amat Baik(AB) & \\
\hline
\end{tabular}

Dari data Tabel 4 di atas, maka dapat dikatakan bahwa hasil analisis siklus I dan analisis pada siklus II terdapat peningkatan sebesar $12,07 \%$, ini berarti ada pengaruh yang sangat baik supervisi kepala sekolah terhadap prestasi kinerja guru-guru SMA Negeri 1 Mendoyo tahun pelajaran 2019/2020. Sedangkan gambar grafik histogram, tentang adanya peningkatan kedua aspek tersebut dapat ditunjukkan seperti berikut ini. 


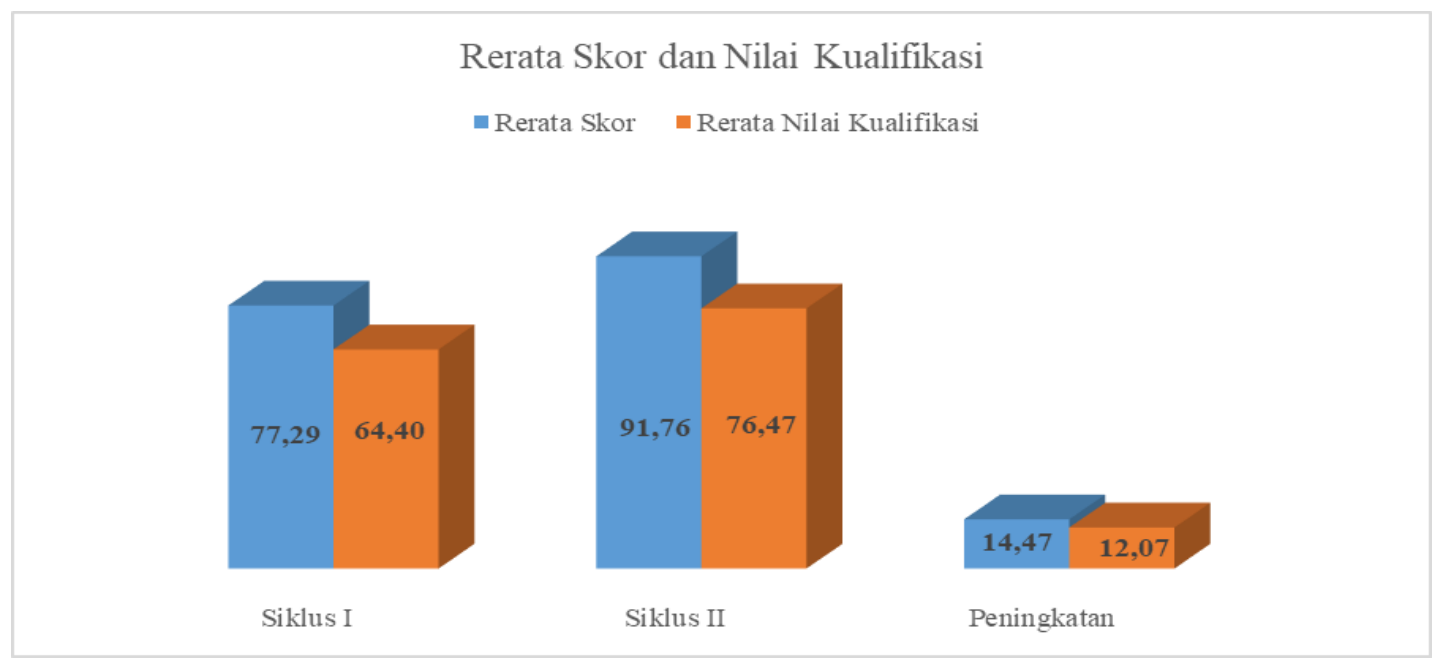

Gambar 3. Grafik Histogram Rerata Prestasi Kinerja Guru

\section{Simpulan dan Saran}

Penelitian Tindakan Sekolah (PTS) ini dilaksanakan sebanyak 2 (dua) siklus yaitu siklus I dilaksanakan pada minggu kedua bulan Agustus 2019 dan Siklus II dilaksanakan pada minggu kedua bulan September 2019, terhadap 42 orang guru diambil seluruhnya jumlah guru yang ada di SMA Negeri 1 Mendoyo. Berdasarkan hasil Analisis data baik siklus I dan siklus II dapat disimpulkan bahwa:

1. Ada peningkatan prestasi kinerja guru yang sangat signifikan melalui Teknik meeting kepala sekolah di SMA Negeri 1 Mendoyo. Ini terbukti dari hasil nilai analisis siklus I rerata persentasenya adalah $64,40 \%$ meningkat menjadi $76,47 \%$.

2. Besarnya pengaruh supervisi kepala sekolah terhadap kinerja guru-guru SMA Negeri 1 Mendoyo dalam penelitian ini adalah 12,07\%.

Sehubungan dengan hasil yang diperoleh dalam penelitian ini, maka dalam rangka perbaikan pelaksanaan program tindakan selanjutnya ada beberapa hal yang perlu mendapatkan perhatian atau disarankan, yaitu sebagai berikut:

1. Untuk perbaikan prestasi kerja guru-guru disarankan untuk mengunakan beberapa supervisi termasuk teknik kelompok dengan pendekatan pertemuan(metting).

2. Dalam penerapan teknik supervisi agar tidak terpaku pada satu teknik saja, sebaiknya mencoba teknik yang lain.

\section{Daftar Pustaka}

Andriani Nutria. 2004. Analisis Iklim Organisasi dan Kepuasan Kerja terhadap Kinerja Karyawan pada PT Bank Mandiri Cabang Malang.Universitas Unibra.

Arikunto,Suharsini.1999. Prosedur Penelitian Suatu Pendekatan Praktek. Jakarta: Rineka Cipta.

Departemen Pendidikan Nasional 2003. Standar Kompetensi Guru Sekolah Menengah Umum,Direktur Tenaga Kependidikan. Jakarta: Depdikbud.

Fitriani, Cut. 2017. Kompetensi Profesional Guru Dalam Pengelolaan Pembelajaran Di Mts Muhammadiyah Banda Aceh . Jurnal Magister Administrasi Pendidikan Volume 5, No. 2, Mei 2017.

Firmansyah, Dani . 2015. Pengaruh Strategi Pembelajaran Dan Minat Belajar Terhadap Hasil Belajar Matematika . Jurnal Pendidikan Unsika Volume 3 Nomor 1, Maret 2015. 
Indonesian Journal of Educational Research and Review, Vol 3 No 1, Tahun 2020

p-ISSN: 2621-4792, e-ISSN: 2621-8984

Jati Sidi,Indra.2001. Menuju Masyarakat Belajar Menggagas Paradigma Baru Pendidikan. Jakarta:Paramadina Logos Wacana IImu.

Kirom, Askhabul . 2017. Peran Guru Dan Peserta Didik Dalam Proses Pembelajaran Berbasis Multikultural . Jurnal Pendidikan Agama Islam Program Studi Pendidikan Agama Islam Universitas Yudharta Pasuruan . Volume 3, Nomor 1, Desember 2017

Majid,Yusuf A.2000. Pengaruh Prilaku Pemimpin Terhadap Kinerja dan Kepuasan Kerja Karyawan Pada Industri Kecil Kembang Gula di Kodya Malang.Malang: Pasca Sarjana UNIBRA.

Nurhadi.2004. Pembelajaran Contekstual dan Penerapannya dalam KBK. Bandung: Rosdakarya.

Surya Dharma. 2010. Penelitian Tindakan Sekolah. Jakarta: PPPPTK.

Suharsini A.2007. Penelitian Tindakan Kelas, Bahan Pelatihan PTK untuk guru, Kepala Sekolah dan Pengawas. Jakarta: Rineka Cipta.

Thahir, Andi. 2014. Pengaruh Bimbingan Belajar Terhadap Prestasi Belajar Siswa Pondok Pesantren Madrasah Aliyah Al-Utrujiyyah Kota Karang. Jurnal Bimbingan dan Konseling 01 (2) (2014).

Undang-Undang Republik Indonesia Nomor 14. Tahun 2005, Undang-Undang Guru dan Dosen. Jakarta: Penerbit Cemerlang. 